1975

\title{
The Equal Protection of Women in Reference to Nationality and Freedom of Movement
}

Lung-chu Chen

New York Law School, lungchu.chen@nyls.edu

Follow this and additional works at: http://digitalcommons.nyls.edu/fac_other_pubs

Part of the Law and Gender Commons, and the Sexuality and the Law Commons

\section{Recommended Citation}

American Society of International Law Proceedings, Vol. 69, pp. 18-24

This Article is brought to you for free and open access by the Faculty Scholarship at DigitalCommons@NYLS. It has been accepted for inclusion in Other Publications by an authorized administrator of DigitalCommons@NYLS. 
women cooperate with other women workers or, remembering how hard they worked to get where they are, do they resent and try to sabotage the progress of colleagues who appear to have had an easier time or better preparation? Most important of all, women in every land and every walk of life must begin to evaluate and use their own potential without nurturing a "will to fail." This psychological handicap has been brought to national attention by my contemporary at Bryn Mawr College, Dr. Matina Horner, who observed:

. . . Among women, the anticipation of success, especially against a male competitor, poses a threat to the sense of femininity and self-esteem and serves as a potential basis for becoming socially rejected-in other words, the anticipation of success is anxiety producing and as such inhibits otherwise positive achievement motivation and behavior. In order to feel or appear more feminine, women, especially those high in fear of success, disguise their abilities and withdraw from the mainstream of thought, activism, and achievement in our society ... ${ }^{5}$

Although Dr. Horner's studies were based on American women, my own experiences while residing and visiting abroad suggest to me that similar motivational blocks may be impeding foreign women from trying to attain the levels of equal achievement which the law officially allows them to reach. Women have a long, long way to go in attitude and education before they can hope to reach their destination of full equality.

Whatever the success or failings may be, the happy juxtaposition of striving for adoption of the Equal Rights Amendment to the United States Constitution and the International Women's Year of the United Nations in 1975 can have one notable result: achieving a greater awareness of the potential of women on the part of men and women throughout the world.

\section{The Equal Protection of Women in Reference to NATIONALITY AND FREEDOM OF MOVEMENT}

\section{By Lung-chu Chen*}

The task assigned to me is to address my remarks to Article 5 and Article 6, paragraph 1 (c) of the Declaration on the Elimination of Discrimination against Women. These provisions deal with the equal protection of women in reference to the right to nationality and to freedom of movement. To paraphrase a traditional aphorism, in matters of nationality it seems that in today's world the husband and the wife are rapidly becoming two instead of one.

${ }^{5}$ Id., 157, 159, 173.

* Yale Law School 
The equal protection of women's right to nationality and to freedom of movement is an important aspect of the emerging norm forbidding all discrimination against women. The increasing global concern for outlawing sex-based discrimination also builds upon and expresses a more general norm of nondiscrimination. This norm seeks to ban all generic differentiations among people in access to value shaping and sharing-for reasons irrelevant to individual capabilities and contribution.

Despite marked improvement in status in recent decades, women around the world still face deep, pervasive, and destructive discrimination. The concept of maleness or femaleness differs in different cultures, and the specific tasks and responsibilities expected of the two sexes vary from one society to another. However, the existence and perpetuation of distinct sex roles, as dictated mostly by men, characteristically result in male-dominated societies in which women are regarded as "the subordinate sex," "the second sex," "the weaker sex," or "the Other." The deprivations imposed on the ground of sex, both historical and continuing, occur in all the value-institutional processes in the shaping and sharing of respect, power, enlightment, well-being, wealth, skill, affection, and rectitude.

In specific reference to the nationality and movement of persons, transnational as well as internal, men and women may of course both suffer deprivations. But in many communities married women are made to suffer additional deprivations under the inherited doctrine that "a woman has no legal existence separate from her husband" who is "head of the family." The acquisition, retention, change, or loss of nationality of a married woman is often made to depend upon the marriage relationship and automatically to follow that of her husband, in disregard of her own wishes. Hence women are more apt to become victims of statelessness or multiple nationality, the hardships of which scarcely need elaboration here. In some communities where women are made to lose civil capacity upon marriage, a married woman cannot obain a passport to travel abroad or emigrate without her husband's permission. Severe restrictions on a married woman's freedom of movement may further result from subjecting her to her husband's decision concerning domicile and residence, without regard to her wishes or interests.

Nationality refers to the "characterizations" state elites make of individuals for the purposes of controlling and protecting them for all their comprehensive concerns. In a world arena still largely state-organized, decisions about nationality may affect both the degree to which the individual person has access to a protecting state in transnational interactions and the substantive content and quality of his or her rights.

The right of nationality importantly affects the freedom of movement, as the barriers to movement are erected along state lines. The degree of freedom of movement is often conditioned by possession of a particular nationality. These two are closely related. In this increasingly inter- 
dependent world, freedom of movement both within the state and across state boundaries is often essential to securing greater fulfillment of all values.

The present inequitable distribution of people in relation to the resources of the world results in significant measure from control of the nationality and movement of people by nation-states. In a fundamental sense what is at stake is the freedom of access of people to resources around the world.

From the standpoint of scholarly observers identified with the whole of humankind, it appears that the long-term policy most compatible with an international law of human dignity would be one that seeks the utmost freedom of choice in group affiliation, participation, and movement. The individual's volition should be accorded the greatest possible expression and respect in all the different decisions concerning nationality. In particular, states should not be permitted to make arbitrary conferment of nationality against the wishes of the individual, that is, upon grounds unrelated to common interest. Nor should states be permitted arbitrarily, as for purposes of discrimination, to deny or withhold nationality sought or possessed by the individual.

Similarly, the utmost freedom of movement should be accorded the individual. Meaningful freedom of movement must entail freedom to leave and enter a territorial community, for temporary and permanent purposes, and to stay, move, and reside within a territorial community. Indeed, freedom of movement is indispensable for progress toward a nonsegregated world of human dignity. In such a nonsegregated world, people, resources, and ideas can move freely to achieve optimum shaping and sharing of all values, and the present disparities in the distribution of people in relation to resources could eventually be redressed equitably around the globe.

It must of course be conceded that, given the present structure of the world arena, states do share some common interests which may require limitation of this preferred policy of the utmost individual freedom of choice in reference to nationality and to movement of people. The preferred policy of freedom of choice needs to be balanced by such public order considerations as the maintenance of security, maintenance of harmonious relations between states, the critical needs of development, health, morals, and so on for the particular community, taking into account also the impact on neighboring and other states, the regional community, and the world community.

The accommodation of common interest with individual freedom in a particular instance would of course require a disciplined, contextual analysis, taking fully into account all the relevant factors in a particular context. But one thing would appear crystal clear: that is, restrictions in regard to nationality and to freedom of movement imposed upon the ground of sex have no relation to rationality.

The group differentiation of individuals upon the basis of sex, for the purpose of allocating access to value processes, including the right 
to nationality and freedom of movement, is as inimical to the fundamental policies of human dignity as group differentiation based upon ethnic characteristics. It cannot promote freedom of choice for the individual to allocate benefits and burdens in social process upon putative qualities of "maleness" or "femaleness" rather than upon the actual characteristics and capabilities of individual persons. Nor can such arbitrary differentiation provide opportunity for the discovering, maturing, and exercising of latent talent, or for self-fulfillment or for contribution to aggregate common interest.

The most rational general community policy requires the complete emancipation of women, without countenancing the subordination of men. Women, like men, should be accorded full freedom of choice and protection in regard to nationality. Nationality should not be imposed on women or taken away from them simply because they happen to marry men of different nationality. Similarly, women, like men, should be accorded the utmost freedom of movement from community to community, and within the community.

The drive toward eradication of sex-based discrimination, like that designed to eliminate racial discrimination, has in recent decades been a vital component of the trend toward a more general norm of nondiscrimination. From the United Nations Charter, through the Universal Declaration of Human Rights, to the International Covenants on Human Rights, the broad, general norm of nondiscrimination has consistently specified "sex" as among the impermissible grounds of differentiation. Significantly, each of the two Covenants contains a special article on the equality of the sexes, obliging the contracting states to "ensure the equal right of men and women to the enjoyment" of all the protected rights. The general norm against sex-based discrimination is further reinforced by a number of conventions, global and regional, and other authoritative expressions oriented toward the protection of women against particular vulnerabilities or in regard to particular values.

In specific reference to the nationality of women, nationality laws differ widely in terms of the effect of marriage. Basically speaking, there are two opposing principles governing the law on the nationality of married women. The traditional principle is the unity of the family, according to which the nationality of all members of the family - mother, father, and children under age - should be the same, in order not to cause split loyalty within the family. The second principle, based on equality of the sexes, honors the freedom of a married woman to choose her own nationality. Under the interplay of these two basic principles, municipal laws about the nationality of married women can be divided into three categories: (1) The nationality of the wife follows automatically that of the husband; (2) Although marriage to a man of a different nationality affects the nationality of the wife, provisions are made to avoid statelessness or double nationality of the woman; and (3) The woman has the right to choose her own nationality and marriage will not affect the nationality of the wife. Thus, according to a recent 
UN study, an alien woman automatically acquires the nationality of her husband upon marriage under the law of twenty-eight states; under the law of sixty-eight states, the alien wife may on certain conditions acquire the nationality of the husband; and under the law of twelve states marriage of an alien woman to a national has no effect whatever on her nationality.

Just as a woman may automatically or otherwise acquire the nationality of her alien husband upon marriage, she may automatically or otherwise lose her original nationality as a consequence of marriage to a foreign national. According to the same UN study, a woman automatically loses her nationality upon marriage to an alien under the law of six states; under the law of 18 states, a woman will automatically lose her original nationality upon acquisition of the nationality of her husband; under the law of the overwhelming majority of the states (84 in number), marriage to an alien husband will not result in automatic loss of nationality.

For the sake of family unity and undivided allegiance, it was once a very popular practice that a woman automatically lost her original nationality and acquired instead her husband's upon marriage to a foreign national. Another justification was phrased in terms of a theory of "implicit consent," i.e., a woman, in marrying an alien, implicitly consents to abandon her original nationality.

From the perspective of human rights, marriage should have no automatic effect on the nationality of either the wife or the husband. An alien woman, in marrying a national, does not necessarily signify her intention formally to identify with the state of which her husband is a national or to sever ties with the state of her nationality. In keeping with the growing demand for equality of men and women, the trend is away from the principle that a married woman's nationality automatically follows that of her husband.

Furthermore, as a manifestation of the policy of minimizing statelessness, the decisive trend has been movement away from automatic loss of a woman's nationality upon marriage to an alien. Thus, the 1930 Hague Convention on Certain Questions relating to the Conflict of Nationality Laws makes the loss of nationality of a woman married to a foreign national, by virtue either of the marriage or of her husband's change of nationality during marriage, conditional on "her acquiring the nationality of the husband." Similarly, the Convention on the Reduction of Statelessness of 1961 makes the loss of a woman's nationality, because of marriage or her husband's loss of nationality, "conditioned upon [her] possession or acquisition of another nationality."

These prescriptions, though protective, are less than adequate. A critical focus in the ongoing worldwide movement of women's liberation has been equality of the sexes regarding nationality. This principle is perceived to be the fundamental, positive answer to the question of statelessness of married women. This positive policy first found concrete expression in the international arena in 1933, when the Montevideo Convention on the Nationality of Women declared that "no 
distinction" shall be "based on sex as regards nationality" and that "neither matrimony nor its dissolution affects the nationality of the husband or wife."

More recently, in 1957, the Convention on the Nationality of Married Women was adopted by the UN General Assembly in an effort to "eliminate the automatic effect on the nationality of the wife of marriage, its dissolution, or the change of nationality by the husband." The principal thrust of the Convention is to substitute the principle of equality between the sexes for the anachronistic doctrine of "the unity of family." The Convention, going beyond such existing prescriptions as embodied in the 1930 Hague Convention on Nationality, stipulates emphatically, in Article 1, that

Neither the celebration nor the dissolution of a marriage between one of its nationals and an alien, nor the change of nationality by the husband during marriage, shall automatically affect the nationality of the wife.

Article 2 states:

Neither the voluntary acquisition of the nationality of another State nor the renunciation of its nationality by one of its nationals shall prevent the retention of its nationality by the wife of such national.

The Convention further provides, in Article 3, that "specially privileged naturalization procedures" be made available for a wife who wishes to acquire the nationality of her husband. The Declaration on the Elimination of Discrimination Against Women of 1967 reaffirms this policy in Article 5:

Women shall have the same rights as men to acquire, change or retain their nationality. Marriage to an alien shall not automatically affect the nationality of the wife either by rendering her stateless or by forcing upon her the nationality of her husband.

Turning to freedom of movement, community expectations have found unequivocal expression in transnational prescriptions. The Universal Declaration of Human Rights in Article 13 proclaims that "Everyone has the right to freedom of movement and residence within the borders of each State" and that "Everyone has the right to leave any country, including his own, and to return to his country." The International Covenant on Civil and Political Rights states in Article 12 that "Everyone lawfully within the territory of a State shall, within that territory, have the right to liberty of movement and freedom to choose his residence:" that "Everyone shall be free to leave any country, including his own;" and that "No one shall be arbitrarily deprived of the right to enter his own country." Comparable provisions are found in the European Convention on Human Rights (Art. 2 of Protocol No. 4) and in the American Convention on Human Rights (Art. 22). These provisions are intended for "everyone," regardless of sex. They apply to women as well as men; they apply to married women as well as unmarried women. The designation "his" used in these provisions is 
employed in generic reference to every person; it in no way purports to exclude the female sex from the purview of the protection.

To highlight the basic unity of humankind in freedom of movement, the Uppsala colloquium was convened in June 1972 to formulate detailed principles for guiding and facilitating the liberal application of the freedom to leave and to return. After spelling out these guiding principles and permissible limitations, the Uppsala Declaration in Article 17 underscores that these principles and limitations be applied without discrimination on the basis of sex, marriage, or other grounds.

Without going into detail, it suffices to say that to the extent freedom of movement is protected on the transnational level, it is imperative that such protection be extended equally to women as well as men. This policy is unequivocably stated in Article 6(1) (c) of the Declaration on the Elimination of Discrimination against Women:

Without prejudice to the safeguarding of the unity and the harmony of the family, which remains the basic unit of any society, all appropriate measures, particularly legislative measures, shall be taken to ensure to women, married or unmarried, equal rights with men in the field of civil law, and in particular: . . .

(c) The same rights as men with regard to the law on the movement of persons.

The Draft Convention on the Elimination of All Forms of Discrimination against Women, currently under consideration by the Commission on the Status of Women, has been accorded priority by the United Nations in 1975, this Intemational Women's Year. Whatever final form this Convention may take, its substantive content is not likely to vary greatly from that of the version presently before the Commission.

In the matter of nationality, the Draft Convention, like the Declaration, seeks to protect women from the bondage and hardships caused by involuntary acquisition, change, retention, or loss of nationality, which automatically result from marriage to an alien husband. Drawing upon the 1957 Convention on the Nationality of Married Women and Article 5 of the Declaration, the Draft Convention provides a detailed formulation in Article 9(1):

States Parties shall grant women the same rights as men to acquire, change or retain their nationality and shall require, in particular, that neither marriage of a woman to, nor dissolution of her marriage from, an alien nor the change of nationality by her alien husband during marriage shall automatically change her nationality, render her stateless or force upon her the nationality of her husband.

The second paragraph of this article urges the grant of nationality to alien women married to nationals "through specially privileged naturalization procedures," as distinguished from those ordinarily applicable to aliens in general. With regard to freedom of movement, Article 15(4) of the Draft Convention specifically includes "the freedom to choose residence" in the protection regarding the "movement of persons."

The authoritative formulation of particular human rights may at first 